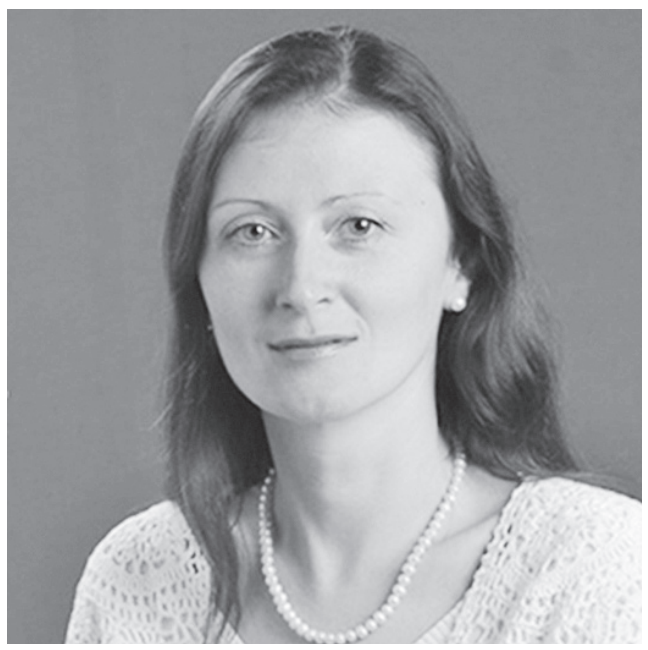

УДК: 35.08 (477)

Пархоменко-Куцевіл Оксана Іеорівна, доктор наук з державного управління, завідувач кафедри публічного адміністрування, Міжрегіональна Академія управління персоналом, 03039, м. Киів, вул. Фрометівська, 2, тел.: (044) 2645254 , e-mail:pkoi@ukr.net

ORCID: 0000-0002-0758-346X

Пархоменко-Кучевил Оксана Игоревна, доктор наук по государственному управлению, заведующий кафедрой публичного администрирования, Межрегиональная Академия управления персоналом, 03039, 2. Киев, ул. Фрометовская, 2, тел.: (044) 26452 54,e-mail:pkoi@ukr.net

ORCID: 0000-0002-0758-346X

Parkhomenko-Kutsevil Oksana Ihorivna, Doctor of Sciences in Public Administration, Head of the Department of Public Administration, Interregional Academy of Personnel Management, 03039, Kyiv, Str. Frometivska, 2, tel.: (044) 264 52 54,e-mail:pkoi@ukr.net

\title{
ПРИНЦИП ДЕЦЕНТРАЛІЗАЦІЇ ЯК ОСНОВА ФОРМУВАННЯ ЯКІСНОГО КАДРОВОГО ПОТЕНЦІАЛУ СИСТЕМИ ПУБЛІЧНОГО УПРАВЛІННЯ
}

Анотація. Проаналізовано можливості удосконалення професійної підготовки кадрів органів місцевого самоврядування з урахуванням реалізації принципу децентралізації. Запропоновано шляхи удосконалення підготовки фахівців органів місцевого самоврядування, передбачено розширення права територіальних громад на вибір не лише вищого навчального закладу, який готуватиме фахівців, а й професійних програм, за якими готуватимуться фахівці для певної територіальної громади.

Проведений аналіз дає підстави виокремити важливі елементи професіоналізації кадрів органів місцевого самоврядування як основу формування децентралізації в Україні, а саме:

1) у чинному законодавстві слід передбачити виділення коштів територіальним громадам на професійне навчання, підвищення кваліфікації посадових осіб місцевого самоврядування. Це надасть можливість громаді обрати, яких саме фахівців для цієї місцевості потрібно підготувати; 
2) необхідно прийняти нормативно-правовий документ, який би передбачав формування реальної потреби у професійному навчанні та підвищенні кваліфікації кадрів органів місцевого самоврядування з урахуванням проведеного моніторингу в потребі саме у таких професійних кадрах;

3) надати територіальним громадам права обирати вищий навчальний заклад, який готуватиме саме тих фахівців, яких потребує даний регіон (населення, громада). Крім того, слід передбачити організацію на базі комунальних навчальних закладів мобільних постійно діючих курсів підвищення кваліфікації посадових осіб місцевого самоврядування із залученням будьяких фахівців з усіх регіонів України за потреби у таких курсах;

4) з метою посилення ролі територіальної громади слід передбачити їі право обирати не тільки вищий навчальний заклад, а й навчальні програми, які потрібні для фахівців, що працюватимуть у цій місцевості;

5) передбачити обов'язок фахівців, які отримали освіту за гроші територіальної громади, відпрацювати в цій громаді протягом 5 років або повернути гроші за професійне навчання;

6) передбачити кошти на фінансування талановитої молоді за кордоном за умови відпрацювання після закінчення навчального закладу певного часу на території України.

Таким чином, система підготовки та підвищення кваліфікації кадрів органів місцевого самоврядування має залежати від потреб регіону в певних компетентностях таких фахівців, а також кількості таких фахівців, що, своєю чергою, можна зробити, якщо надати право територіальній громаді здійснювати моніторинг потреби в кадрах та право громад замовляти професійне навчання або підвищення кваліфікації. Крім того, потрібно надати право територіальним громадам обирати не лише вищий навчальний заклад, де здійснюють підготовку кадрів органів місцевого самоврядування, а й навчальні програми, за якими здійснюватиметься така підготовка.

Ключові слова: державна служба, служба в органах місцевого самоврядування, кадри, кадровий потенціал, децентралізація, розвиток, навчання, підвищення кваліфікації кадрів.

\section{ПРИНЦИП ДЕЦЕНТРАЛИЗАЦИИ КАК ОСНОВА ФОРМИРОВАНИЯ КАЧЕСТВЕННОГО КАДРОВОГО ПОТЕНЦИАЛА СИСТЕМЫ ПУБЛИЧНОГО УПРАВЛЕНИЯ}

Аннотация. Проанализированы возможности совершенствования профессиональной подготовки кадров органов местного самоуправления с учетом реализации принципа децентрализации. Предложены пути совершенствования подготовки специалистов органов местного самоуправления, предусмотрено расширить право территориальных общин на выбор не только высшего учебного заведения, который будет готовить специалистов, но и профессиональных программ, по которым будут готовить специалистов для определенной территориальной общины. 
Проведенный анализ позволяет выделить важные элементы профессионализации кадров органов местного самоуправления как основу формирования децентрализации в Украине, а именно:

1) в действующем законодательстве следует предусмотреть выделение средств территориальным общинам на профессиональное обучение, повышение квалификации должностных лиц местного самоуправления. Это позволит обществу выбрать каких именно специалистов для этой местности нужно подготовить;

2) необходимо принять нормативно-правовой документ, который бы предусматривал формирование реальной потребности в профессиональном обучении и повышении квалификации кадров органов местного самоуправления с учетом проведенного мониторинга о необходимости именно в таких профессиональных кадрах;

3) предоставить территориальным общинам право избирать высшее учебное заведение, которое будет готовить именно тех специалистов, в которых нуждается данный регион (население, община). Кроме того, следует предусмотреть организацию на базе коммунальных учебных заведений мобильных постоянно действующих курсов повышения квалификации должностных лиц местного самоуправления по привлечению любых специалистов из всех регионов Украины при необходимости в таких курсах;

4) для усиления роли территориальной общины следует предусмотреть право общины выбирать не только высшее учебное заведение, но и учебные программы, необходимые специалистам для работы в данной местности;

5) предусмотреть обязанность специалистов, получивших образование за деньги территориальной общины, отработать в этой общине в течение 5 лет или вернуть деньги за профессиональное обучение;

6) предусмотреть средства на финансирование талантливой молодежи за рубежом при условии отработки после окончания учебного заведения определенного времени на территории Украины.

Таким образом, система подготовки и повышения квалификации кадров органов местного самоуправления должна зависеть от потребностей региона в определенной компетентности таких специалистов, а также количества таких специалистов, что, в свою очередь, можно сделать, если предоставить право территориальной общине осуществлять мониторинг потребности в кадрах и право общин заказывать профессиональное обучение или повышение квалификации. Кроме того, нужно предоставить право территориальным общинам выбирать не только высшее учебное заведение, где осуществляют подготовку кадров органов местного самоуправления, но и учебные программы, по которым будет осуществляться такая подготовка.

Ключевые слова: государственная служба, служба в органах местного самоуправления, кадры, кадровый потенциал, децентрализация, развитие, обучение, повышение квалификации кадров. 


\section{THE PRINCIPLE OF DECENTRALIZATION AS A BASIS FOR THE FORMATION OF A QUALITATIVE HUMAN RESOURCES POTENTIAL OF THE PUBLIC ADMINISTRATION SYSTEM}

Abstract. The article analyzed the possibilities of improving the professional training of local government staff taking into account the implementation of the principle of decentralization. The ways of improving the training of specialists of local self-government bodies are proposed, it is envisaged to expand the right of territorial communities to choose not only a higher educational institution that will train specialists but also professional programs that will prepare specialists for a particular territorial community.

The analysis provided grounds for highlighting important elements of the professionalization of local government staff as the basis for the formation of decentralization in Ukraine.

1) The current legislation should provide for the allocation of funds to territorial communities for vocational training, raising the skills of local government officials. This will enable the community to select which professionals to prepare for this area.

2) It is necessary to adopt a normative legal document that would provide for the formation of a real need for vocational training and professional development of local government personnel, taking into account the monitoring carried out in need in such professional personnel.

3) Provision of territorial communities with the right to choose a higher educational institution that will train specialists who need this region (population, community). In addition, it is necessary to foresee the organization on the basis of municipal educational establishments of mobile permanent courses of training of officials of local self-government with the involvement of any specialists from all regions of Ukraine, if necessary in such courses.

4) In order to strengthen the role of the territorial community, it should be foreseen the right of the community to choose not only a higher educational institution, but also the curricula that are required for professionals who work in the area.

5) To oblige the specialists who have received education for the money of a territorial community, to work in this community for 5 years or to return the money for professional training.

6) Provide funds for the financing of talented youth abroad, provided that they work after graduation of a certain time in Ukraine.

The system of training and advanced training of staff of local self-government bodies should depend on the needs of the region in certain competencies of such specialists, as well as the number of such specialists, which in turn can be made if the territorial community is empowered to monitor the needs of staff and the right of communities to order professional training or advanced training. In addition, it is necessary to give territorial communities the right not only to choose a higher educational institution, which trains local self-government personnel, but also curricula for which such training will be carried out. 
Keywords: public service, service in local self-government bodies, personnel, personnel potential, decentralization, development, training, personnel training.

Постановка проблеми в загальному вигляді та ії зв'язок із важливими науковими або практичними завданнями. На сьогодні проблеми децентралізації аналізуються політологами, соціологами, економістами, фахівцями з державного управління. Водночас на даний момент актуалізуються проблеми аналізу питання децентралізації з точки зору формування кадрового потенціалу системи публічного управління.

Кадри є основою якісних реформ у державі, оскільки саме публічні службовці формують та реалізують управлінські рішення, прогнозують можливі наслідки таких рішень та коригують їх. Тому децентралізація як головна реформа країни потребує спеціально підготовлених кадрів, які б мали не лише професійні знання в галузі публічного управління, а й могли їх застосовувати на практиці.

Так, кадри системи публічного управління формуються централізовано в системі закладів вищої освіти не залежно від потреб регіонів у певних управлінських якостях та певній спеціалізації (зокрема, управління аграрною галуззю, освітньою тощо). Крім того, професійне навчання спрямоване на опанування базовими професійними навичками в системі публічного управління, не враховуючи потребу в таких фахівцях, особливо щодо управління на регіональному рівні. Окремо існує проблема відсутності у фахівців практичних навичок в управлінських ситуаціях.
Нині постало питання формування кадрового складу залежно від потреб територіальної громади з урахуванням запитів сучасного суспільства та інформаційного глобалізаційного простору.

Аналіз останніх досліджень і публікацій. Проблеми формування та розвитку кадрів на державній службi, органах місцевого самоврядування, визначення історичних закономірностей розвитку кадрів системи державного управління аналізують українські та закордонні вчені, у тому числі: В. Авер'янов, О. Антонова, Г. Атаманчук, Н. Гончарук, В. Малиновський, Р. Науменко, Н. Нижник, О. Оболенський, В. Олуйко, С. Охотський, А. Рачинський, С. Серьогін, А. Сіцінський, I. Сурай, О. Турчинов, С. Хаджирадєва, О. Якубовський та ін. Згадані вчені розглядають сучасні тенденції розвитку кадрів системи державного управління, проблеми формування кадрів у системі державної служби, відбір та конкурсні процедури, основні етапи реформування та модернізації державної служби України. Водночас український вчений М. Карпа аналізує методи управління кадровими процесами у контексті становлення публічної служби в Україні.

Недостатньо дослідженими залишаються сучасні аспекти кадрового забезпечення та проблеми підготовки управлінських кадрів для органів місцевого самоврядування. 
Таким чином, невирішеною раніше частиною загальної проблеми $€$ обгрунтування принципу децентралізації як основи формування якісного кадрового потенціалу системи публічного управління.

Постановка завдання. У дослідженні передбачено на підставі проведення системного аналізу обгрунтувати реалізацію принципу децентралізації як основи формування якісного кадрового потенціалу системи публічного управління

Виклад основного матеріалу. Відповідно до Закону України "Про службу в органах місцевого самоврядування” посадами в органах місцевого самоврядування є [2]:

- по-перше, виборні посади, на які особи обираються на місцевих виборах; виборні посади, на які особи обираються або затверджуються відповідною радою;

- по-друге, посади, на які особи призначаються сільським, селищним, міським головою, головою районної, районної у місті, обласної ради на конкурсній основі чи за іншою процедурою, передбаченою законодавством України.

Слід зауважити, що у законі не визначено основні вимоги щодо підготовки осіб місцевого самоврядування, що є важливим аспектом розвитку децентралізації, оскільки саме кадри формують та реалізують регіональну політику, визначають пріоритети розвитку регіону, формують генеральні плани міст тощо. Від кваліфікації кадрів системи місцевого самоврядування залежить не лише постійний розвиток регіонів, а й реформування системи управління регіоном.
Отже, професійна підготовка посадових осіб органів місцевого самоврядування повинна різнитися залежно від категорії посад та потреб у певних навичках та знаннях, адже для кожної категорії посад характерний різний набір компетеностей.

Відповідно до Концепції реформування системи професійного навчання державних службовців, голів місцевих державних адміністрацій, їх перших заступників та заступників, посадових осіб місцевого самоврядування та депутатів місцевих рад, професійний розвиток державних службовців, голів місцевих держадміністрацій, їх перших заступників та заступників, посадових осіб місцевого самоврядування - безперервний, свідомий, цілеспрямований процес особистісного та професійного зростання, що базується на інтеграції знань, умінь і компетентностей [5].

Система професійного навчання державних службовців, голів місцевих держадміністрацій, їх перших заступників та заступників, посадових осіб місцевого самоврядування, депутатів місцевих рад є цілісною сукупністю взаємопов'язаних компонентів, що включає:

- визначення потреб у професійному навчанні;

- формування, розміщення і виконання державного замовлення;

- формування мотивації до підвищення рівня професійної компетентності;

- забезпечення функціонування і розвитку ринку надання освітніх послуг у сфері професійного навчання;

- моніторинг та оцінку якості навчання [5]. 
У зазначеній Концепції не виокремлено етапи професійного навчання саме посадових осіб місцевого самоврядування. Однак, на нашу думку, етапи професійного навчання посадових осіб місцевого самоврядування мають свою специфіку. Головне - професійні знання, практичні навички, які потрібні посадовим особам місцевого самоврядування, мають галузеву спрямованість, водночас зазначені фахівці повинні володіти питаннями формування та виконання місцевого бюджету, поділу видатків 3 місцевого бюджету, а також розуміти систему місцевого самоврядування та систему публічного управління.

Тому в системі професійного навчання посадових осіб місцевого самоврядування важливим є визначення потреби у відповідних компетентностях.

Професійне навчання посадових осіб органів місцевого самоврядування повинно мати притаманні тільки йому риси і грунтуватися на таких засадах [1]:

- регулярне вивчення потреб навчання й оцінки кадрових змін;

- дотримання чинних нормативно-правових актів про підвищення кваліфікації;

- вибір видів і термінів підвищення кваліфікації працівників з урахуванням результатів їхнього навчання у попередні роки;

- вибір видів і термінів підвищення кваліфікації працівників з урахуванням специфіки посад;

- першочерговість навчання працівників, уперше обраних або прийнятих на посаду;

- удосконалення навчальних програм з метою задоволення потреб у навчанні слухачів, розвитку їхніх умінь і навичок, професіоналізму;

- класифікація службовців місцевого самоврядування за потребами в навчанні.

Національна система підготовки, спеціалізації та підвищення кваліфікації державних службовців і посадових осіб органів місцевого самоврядування в Україні утворена й функціонує з метою задоволення потреби центральних і місцевих органів виконавчої влади, органів місцевого самоврядування, інших органів та організацій, на які поширюється дія законів України "Про державну службу" та "Про службу в органах місцевого самоврядування" у високопрофесійних і висококультурних працівниках, здатних компетентно й відповідально виконувати управлінські функції, впроваджувати новітні соціальні технології, сприяти інноваційним процесам реформування системи державного управління та місцевого самоврядування. До державної системи підготовки, насамперед, належать такі інституції: Національна академія державного управління при Президентові України та іï регіональні інститути; інші вищі навчальні заклади, які здійснюють підготовку магістрів за спеціальністю "Публічне управління та адміністрування"; регіональні центри перепідготовки та підвищення кваліфікації працівників органів державної влади, органів місцевого самоврядування, державних підприємств, установ і організацій; державні (галузеві) заклади післядипломної освіти [3].

Слід зауважити, що хоча й існує розгалужена мережа закладів, які 
навчають, підвищують кваліфікацію кадрів органів місцевого самоврядування, а також навчальні програми, за якими здійснюються ці процеси, в Україні освіта та підвищення кваліфікації посадових осіб місцевого самоврядування не пов'язані з реальними ситуаціями, функціональними обов'язками, які виконують фахівці. Крім того, в освітніх програмах не враховується освітній рівень фахівця.

На нашу думку, основними засадами навчання кадрів органів місцевого самоврядування мають стати: професіоналізм; відповідальність; підзвітність; принцип випереджального характеру (підготовка має спрямовуватися на майбутнє, опанування новітніх технологій, інноваційних методів роботи); ефективність; інноваційність; практична спрямованість; індивідуальний підхід тощо.

Таким чином, новий підхід до навчання кадрів органів місцевого самоврядування має бути зорієнтованим на специфіку діяльності фахівця, гарантувати результати діяльності, передбачати спеціальну професійну підготовку вищих керівних кадрів, визначати обов'язковим навчання фахівця після призначення його на посаду, а також у зв'язку зі зміною державної політики, прийняттям нових нормативно-правових актів.

Існує безпосередній взаємозв'язок навчання (підготовки) посадових осіб місцевого самоврядування зі змінами, що відбуваються у державному управлінні сьогодні. Так, до 1990 р. майже усі рішення в республіках колишнього Радянського Союзу проходили через управлінські органи, що розміщувалися у Москві.
Республіканські міністерства підпорядковувалися союзним. Місцевий апарат державного управління переважно слугував для виконання вказівок, а не для самостійного вироблення політики та прийняття рішень. У період переходу від командно-адміністративної системи до демократичної якісно змінюється механізм функціонування держави, яка на сьогодні покликана слугувати суспільству, надавати послуги населенню. 3 огляду на це істотно змінюються i функції державних службовців: сучасні суспільні перетворення потребують не виконавців, а активних суб'єктів реформування державного управління [4, с. 36-37].

Таким чином, нині перед Українською державою стоїть нагальна проблема нового осмислення ролі кадрів органів місцевого самоврядування та “виховання” саме таких фахівців, які б змогли на сучасному етапі вирішувати проблеми, що постають у процесі здійснення децентралізації.

Проведений аналіз дає підстави виокремити важливі елементи професіоналізаціі кадрів органів місцевого самоврядування як основу формування децентралізації в Україні.

По-перше, у чинному законодавстві слід передбачити виділення коштів територіальним громадам на професійне навчання, підвищення кваліфікації посадових осіб місцевого самоврядування. Це дасть можливість громаді обрати, яких фахівців для цієї місцевості потрібно підготувати.

По-друге, потребує прийняття нормативно-правового документа, який би передбачав формування реальної потреби у професійному 
навчанні та підвищенні кваліфікаціі кадрів органів місцевого самоврядування з урахуванням проведеного моніторингу в потребі саме у таких професійних кадрах.

По-третє, надання територіальним громадам права обирати вищий навчальний заклад, який готуватиме саме тих фахівців, яких потребує даний регіон (населення, громада). Крім того, слід передбачити організацію на базі комунальних навчальних закладів мобільних постійно діючих курсів підвищення кваліфікації посадових осіб місцевого самоврядування із залучення будь-яких фахівців з усіх регіонів України за потреби у таких курсах.

По-четверте, з метою посилення ролі територіальної громади слід передбачити право громади обирати не тільки вищий навчальний заклад, а й навчальні програми, які потрібні для фахівців, що працюватимуть у даній місцевості.

По-п'яте, передбачити обов'язок фахівців, які отримали освіту за гроші територіальної громади, відпрацювати в цій громади протягом 5 років або повернути гроші за професійне навчання.

По-шосте, передбачити кошти на фінансування талановитої молоді за кордоном за умови відпрацювання по закінченні навчального закладу певного часу на території України.

Таким чином, система підготовки та підвищення кваліфікації кадрів органів місцевого самоврядування повинна залежати від потреб регіону в певних компетентностях таких фахівців, а також їх кількості, що, своєю чергою, можна зробити, якщо надати право територіальній громаді здійс- нювати моніторинг потреби в кадрах та право громад замовляти професійне навчання або підвищення кваліфікаціі. Крім того, потрібно надати право територіальним громадам обирати не лише вищий навчальний заклад, де здійснюють підготовку кадрів органів місцевого самоврядування, а й навчальні програми, за якими здійснюватиметься така підготовка.

Висновки. У статті проаналізовано можливості удосконалення професійної підготовки кадрів органів місцевого самоврядування 3 урахуванням реалізації принципу децентралізації. Запропоновано шляхи вдосконалення підготовки фахівців органів місцевого самоврядування, передбачено розширення права територіальних громад на вибір не тільки вищого навчального закладу, який готуватиме фахівців, а й професійних програм, за якими готуватимуть фахівців для певної територіальної громади.

y перспективі подальших розвідок передбачено проаналізувати закордонний досвід формування принципу децентралізації, а також підготовки фахівців за замовленням територіальної громади.

\section{СПИСОК ВИКОРИСТАНИХ ДЖЕРЕЛ}

1. Дімова О. В. Особливості кадрового забезпечення служби в органах місцевого самоврядування. URL: http://www.kbuapa.kharkov.ua/ebook/db/2007-1-1/doc/3/05.pdf (дата звернення 16.10.2018 р.).

2. Закон України про службу в органах місцевого самоврядування. URL: http://zakon.rada.gov.ua/ 
laws/show/2493-14 (дата звернення 16.10.2018 p.).

3. Інформаційно-аналітичний звіт "Аналіз ситуації щодо професійної підготовки, перепідготовки та підвищення кваліфікації державних службовців посадових осіб органів місцевого самоврядування в Україні”. URL: http://pleddg.org. ua/wp-content/uploads/2017/07/ Analytical-report_InstitutionTraining-2017_7July_Final.pdf (дата звернення 16.10.2018 р.).

4. Опанасюк $Г$. Тенденції підготовки державних службовців у країнах Центральної та Східної Свропи. К. : Вид-во УАДУ, 2001. - 284 с.

5. Про схвалення Концепції реформування системи професійного навчання державних службовців, голів місцевих державних адміністрацій, ix перших заступників та заступників, посадових осіб місцевого самоврядування та депутатів місцевих ради: розпорядження Кабінету Міністрів України від 01.12.2017 р. № 974. URL: http://zakon.rada.gov. ua/laws/show/974-2017-\%D1\%80 (дата звернення 16.10.2018 р.).

\section{REFERENCES}

1. Dimova O. V. (2007) Features of personnel support of the service in local self-government bodies [Online] avai- lable at: http:// www.kbuapa.kharkov. ua/e-book/db/2007-1-1/dots/3/05. pdf (Accessed 16.10.2018).

2. The Verkhovna Rada of Ukraine (2001), The Law of Ukraine " On service in local self-government bodies", available at: http://zakon.rada. gov.ua/lavs/shov/2493-14 (Accessed 16.10.2018).

3. Informational and analytical report "Analysis of the situation regarding vocational training, retraining and professional development of civil servants of officials of local self-government bodies in Ukraine" (2017) available at: http://pleddg.org.ua/vp-tsontent/ uploads/2017/07/Analytitsal-report Institution-Training-2017_7Yuly_Final.pdf (Accessed 16.10.2018).

4. Opanasiuk H. (2001) "Trends in the training of civil servants in Central and Eastern Europe", Vyd-vo UADU, Kyiv, Ukraine.

5. Cabinet of Ministers of Ukraine (2017), "Resolution of the Cabinet of Ministers of Ukraine" On Approving the Concept of Reforming the System of Professional Training of Civil Servants, Heads of Local State Administrations, their First Deputy and Deputy, Local Government Officials and Local Council Deputies, available at: http://zakon.rada.gov.ua/lavs/ shov/974-2017-\%D1\%80 (Accessed 16.10.2018). 